\title{
SNP - LABOUR COALITION: A DREAM OR A REALITY?
}

\begin{abstract}
This article is an attempt to analyse the collaboration between the Labour and the Scottish nationalists in the context of the formation of the modern British political agenda. The participants of the British political space, being concerned about the questions of the United Kingdom leaving the European Union, inevitably face a number of challenges, and the problem of their internal interaction remains one of the most significant. Opposition parties are at an impasse: the Brexit negotiations seem as good as paralysed. The Prime Minister is being put in a very difficult position: a motion of no confidence in December, the failure of her proposals for the Brexit deal in January. The ruling conservative party itself is deeply divided. Every now and then there are some calls for a second United Kingdom European Union membership referendum. And in that event, to which extent is the opposotion coalition possible - the Labor Party and the Scottish nationalists? And if so, what are its future prospects?

Key words: Scottish national party; Labour party; Nicola Sturgeon; Jeremy Corbyn; Brexit; referendum; European Union.
\end{abstract}

About the author: Diana Anatolyevna Kozlova, Candidat of Historical Sciences, senior lecturer.

Place of employment: Higher School of Business of the Southern Federal University.

Козлова Д.А. Шотландская национальная партия - лейбористы: коалиция - утопия или реальность? // Вестник Нижневартовского государственного университета. 2019. № 3. С. 17-23.

Kozlova D.A. SNP - labour coalition: a dream or a reality? // Bulletin of Nizhnevartovsk State University. 2019. No. 3. P. 17-23.

УДК 94(430)

Л. Н. Беспалова

Нижневартовск, Россия

\section{ПОЛИТИЧЕСКИЕ ПАРТИИ КАК РЕСУРС ДЛЯ СОЦИАЛЬНОГО РЕФОРМИРОВАНИЯ ГЕРМАНИИ В 70-е ГОДЫ ХІХ ВЕКА}

Аннотация. В статье анализируется роль политических партий и иныХ политических ресурсов в условиях социального реформирования Германской империи в 70-е гг. ХІХ в. Автор относит к политическим ресурсам не только политические партии и движения, но и профессиональные объединения, предпринимательские группы, демонстрирующие определенную степень социальной ответственности. Указанный период во внутренней политике рейхсканцлера О. Бисмарка был отмечен активным поиском единомышленников в лице представителей различных политических партий, экономистов, крупных промышленников для разработки и проведения социальных реформ. Автор показал, что в поисках социальной опоры общегерманского государства О. Бисмарк продемонстрировал умение лавировать между политическими партиями и группами, предпринимательскими и иными социальными слоями. В статье акцентируется внимание на стратегии рейхсканцлера, которая состояла в снижении остроты политических и социальных проблем, создании социального баланса между различными общественными слоями. Автор особо отмечает, что глава правительства Германской империи не только стремился за счет социальных уступок изолировать рабочий класс от социал-демократии, но и путем социального реформаторства сохранить мир и согласие в новом, индустриальном немецком обществе, открыть дорогу к его консолидации, а затем и стабильности. Автор уделяет особое внимание структуре, организации и влиянию партий. Представлены статистические сведения о процентном соотношении избирателей, голосовавших за ту или иную партию, а также о количестве полученных по результатам выборов в парламент депутатских мандатов. Интерес представляет характеристика политических программ различных партий.

Ключевые слова: партия; либералы; консерваторы; прогрессисты; социал-демократы; Отто фон Бисмарк; парламент; рейхстаг; юнкерство.

Сведения об авторе: Людмила Николаевна Беспалова, старший преподаватель кафедры документоведения и всеобщей истории. 
Место работы: Нижневартовский государственный университет.

Контактная информация: 628605, Россия, г. Нижневартовск, ул. Ленина, д. 56; тел.: (3466)27-35-10, e-mail: biespalova_80@mail.ru.

Путь к социальному реформированию, заключавшемуся прежде всего в выработке законодательной базы, всегда сопровождается немалыми трудностями. Перед государственными властями встают проблемы, связанные с политическими ресурсами создания нормативно-правового фундамента. В тогдашних германских условиях к политическим ресурсам можно отнести в первую очередь политические партии и движения, профессиональные объединения, предпринимательские группы, демонстрирующие определенную степень социальной ответственности.

В Германской империи в рассматриваемое время продолжался процесс формирования многопартийной системы как суммы политических партий.

Правая сторона политических сил Германии имела консервативный характер - этот вывод можно сделать на основе выборов в 1871 г., где консерваторы получили $23 \%$ голосов и 94 мандата в парламент (Бонвеч 2008b: 270). В декабре 1870 г. появляется католическая немецкая партия Центра. Ее название было заимствовано от другой существовавшей раннее (50-60-е гг.) католической фракции, которая работала в парламенте Пруссии. Впрочем, прямой организационной связи Центра с политическими и идеологическим предшественниками не прослеживается, полагает О.В. Ольховская в своей диссертации (Ольховская 2014: 73). Название партии Центр, часто используемое в политической и обыденной лексике, ничего общего не имеет с центристской позицией. Немецкая партия Центра была на правом крае партийного поля в Германии.

Наибольшее политическое влияние Центр имел на юге и западе империи, а так же в Эльзасе, Лотарингии и польских землях, где проживало значительное число католиков. Организовывая свою деятельность по религиозному принципу, Центр смог себе обеспечить широкую базу поддержки населения, не в последнюю очередь потому партия не ориентировалась на определенные социальные группы.

Немецкую партию Центра на парламентских выборах 1871 г. поддержали 18,6\% избирателей - 724 тыс. человек из более 4 млн имеющих право голоса, через три года (1874) - 27,9\% (1 млн 446 тыс. человек); количество мандатов партия увеличила с 63 до 91 (Ritter, Niehuss 1980: 38).

Центр имел строгую организацию, чего нельзя сказать о либеральных партиях. В распоряжении партии была разветвленная сеть католических союзов и объединений (Salomon 1924: 25). Основные лозунги Центра строились на вечных постулатах христианства, которое основывалось на традициях и обычаях. Традиционализм воспринимал индустриализацию, научно-техническое развитие, идеи социализма и либерализма негативно, выступал за возвращение к христианскому образу жизни. Так же они решительно осуждали излишний контроль О. Бисмарка над обществом, подчеркивая необходимость защиты суверенитета католиков (Specht 1898: 352).

Что касается «устранения социальной несправедливости и поддержки всех интересов рабочего сословия», то немецкая партия Центра предлагала в своей программе от 30 июня 1870 г. достичь этого «посредством здорового христианского воспитания» (Бонвеч 2008b: 252). В новой партийной программе, обнародованной в феврале 1871 г., предлагались уже конкретные социальные меры: организация рабочего сословия и ремесленников на корпоративных началах; законодательная защита женского и детского труда от эксплуатации их властью капитала; защита трудящихся посредством издания законов о рабочем времени и воскресном отдыхе; защита здоровья и жи- 
лищ, принадлежащих трудящимся в рабочих поселках; учреждение инспекции, контролирующей соблюдение законов о защите рабочего сословия» (Бонвеч 2008b: 262).

Резюмируя суждения о партии Центра, можно согласиться с О.В. Ольховской, которая утверждала, что эта партия фактически отстаивала «идею создания социально ориентированного государства и общества» (Ольховская 2014: 73).

Еще одной консервативной партией парламента была Партия свободных консерваторов, ставшая потом Немецкой имперской партией; она имела в рейхстаге 37 мандатов. Партия не могла похвастаться широкой социальной базой, но обладала хорошей организацией и влиянием. На выборах 1874 г. за партию проголосовали 376 тыс. избирателей $(7,2 \%)$; количество мандатов партии уменьшилось до 33 (Ritter, Niehuss 1980: 38).

Немецкая имперская партия стояла на защите интересов крупных землевладельцев и промышленников Вестфалии и Рурской области, а потому ее в прессе и в широких кругах общественности называли «союзом ржи и стали». Партии симпатизировало высшее чиновничество. В 70 -е и 80-е гг. XIX в. партия инициировала повышение таможенных тарифов. Немецкая имперская партия полностью поддерживала стремления рейхсканцлера объединить Германию и сохранить существующий политический строй (Treue 1956: 61-62). Одним словом, Бисмарк мог всегда рассчитывать на свободных консерваторов при проведении своей политики социального реформирования.

С 1876 г. на правом фланге политического поля Германии находилась Немецкая когсервативпая партия (НКП). Опа была в почете среди юнкерства, прусской бюрократии и офицерства, духовенства и зажиточного крестьянства. Налаживались отношения партии с населением через деятельность профессиональных политиков. На парламентских выборах 1877 г. НКП получила значительную поддержку. НКП очень рьяно боролась с другими политическими силами империи. В своей программе, которая вышла в 1876 г., партия заявила о необходимости борьбы с социалистическими учениями (История Германии 2008b: 262263), а также о целесообразности разработки «хорошего рабочего законодательства», которое могло бы обеспечить «мирное сотрудничество работодателей и работников» (Бонвеч 2008b: 263). НКП в 1893 г. помогла сельским жителям создать «Союз сельских хозяев», подталкивая в его ряды мелкое и среднее крестьянство.

В результате такого симбиоза с «Союзом сельских хозяев» НКП удалось массово расширить социальную базу партии. К тому же НКП не считала зазорным брать на вооружение некоторые лозунги из народнической идеологии «крови и почвы» и даже из антисемитизма. Одним словом, НКП обладала большим политическим весом в рейхстаге.

Антагонистами консерваторам были либеральные партии. В 1870-е гг. самой влиятельной их них была Националлиберальная партия (НЛП) (Устинова 2011: 201); в 1871 г. на выборах в имперский парламент НЛП получила $30 \%$ голосов, создав самую большую фракцию (125 депутатов); на следующих выборах 1874 г. она набрала 29,7\% голосов (155 мандатов) (Бонвеч 2008b: 270). Ее базу составляли представители крупных промышленных и торговых предпринимателей, бюрократов и буржуазной интеллигенции. Они были приверженцами централизованной Германии, поэтому поддерживали О. Бисмарка, однако считали, что нужно учитывать специфику регионов. Несмотря на то, что в 1870-е гг. представители НЛП имели парламентское большипство, опи пе стремились ограничивать авторитарную политику канцлера.

Социальному вопросу НЛП не уделяла много внимания. Изначально они заявляли, что государство не должно вмешиваться в социально-экономические отношения, но экономический кризис 70-х гг. 
расколол партию на два противоборствующих лагеря, из-за чего уровень ее влияния в парламенте значительно снизился. Спор между партийцами заключался в проведении политики протекционизма, где только половина поддержала ее проведение. В итоге вектор партии постепенно переместился вправо. Для сохранения своей политической силы НЛП поддержала политику колониальной экспансии и усиления военно-промышленного комплекса.

Левее НЛП на политическом поле Германии находилась Немецкая прогрессистская партия, занимавшая в парламенте 46 мандатов (Ritter, Niehuss 1980: 38). Партию поддерживали представители средних и мелкобуржуазных слоев. Когда во главе партии стоял О. Рихтер, ее курс бы направлен на критику чрезмерной бюрократизации и централизации общества; он предлагал создать контроль парламента над правительством, где исполнительная власть была бы обязана вести отчетность о своих действиях. Когда пришел новый лидер партии Ф. Науманн, были предприняты робкие попытки наладить контакты с социалдемократами, однако большая часть партии отнеслась к этому негативно.

На политическом ландшафте Германии в рассматриваемое время находилась и Немецкая народная партия, созданная в 1868 г. Она стояла в оппозиции к Бисмарку с момента создания Германской империи. Немецкая народная партия на выборах 1971 г. набрала немного - 0,5\%. И лишь один представитель этой партии был в рейхстаге (Ritter, Niehuss 1980: 38). Тем не менее, голос партии был слышен; она была известна критикой прусско-германской монархии, настойчиво требовала демократических реформ, в частіости, выступала за усиление полномочий рейхстага, который не участвовал по конституции в формировании правительства и не оказывал нужного влияния на политику исполнительной власти. Немецкая народная партия была самой левой среди немарксистских партий и располагалась ближе всего к социал-де- мократам из центристских партий. Это была единственная либеральная партия, сотрудничавшая с социалистами в рейхстаге.

И наконец, на левом фланге партийного поля Германии была Социал-демократическая рабочая партия (СДРП), созданная в 1869 г. В 1871 г. на выборах в рейхстаг за партию проголосовало 124 тысо избирателей $(3,2 \%)$; этот результат позволил им иметь в рейхстаге двух своих представителей (Бонвеч 2008b: 270). В последующие годы партия набирала политический вес: после выборов 1874 г. СДРП, получив 6,8\% (352 тыс. голосов), стала обладать 9 мандатами. В 1875 г. после объединения с Всеобщим германским рабочим союзом СДРП стала называться Социалдемократической партией Германии (СДПГ). На выборах 1877 г. за партию уже проголосовали почти полмиллиона избирателей; фракция социалистов увеличилась до 12 человек (Ritter, Niehuss 1980: 38).

Итак, можно заключить, что политический ресурс в виде политических партий, в большей или меньшей степени демонстрирующих свою заинтересованность в решении социальных проблем, в Германии присутствовал. Бисмарку предстояло приложить громадные усилия для того, чтобы вместе с политическим партиями, заинтересованными в разрешении социальнополитического конфликта, приступить к созданию социального законодательства в парламенте страны - рейхстаге.

Что касается изложения характера взаимоотношений Бисмарка и рейхстага, то в исторической литературе преобладает, к сожалению, картина крайне негативного отношения рейхсканцлера к парламенту. Историки еще времен императорской России, в частпости В.Н. Решшенкампф, считали, что рейхсканцлер и его сторонники «придерживались мысли о том, что лишь сильная и независимая монархическая власть способна защитить каждого и вести общество к высшим целям, лишь она, а не парламентарии с их мелкими частными интересами, является истинной выразитель- 
ницей народной воли» (Ренненкампф 1890: 126). Здесь необходимо уточнить: Бисмарк, воспитанный семьей и окружением как монархист, тем не менее, на протяжении всей своей жизни являлся приверженцем ограниченной конституционной монархии.

Современные российские исследователи не соглапаются с утверждениями о том, что Бисмарк был «решительным противником парламентской системы» (Чупрова 2009: 280). Бисмарк считал парламент таким государственным учреждением, которое объединяет в себе силы, способные противостоять центробежным тенденциям (Бисмарк 1940b: 275). Учитывая нерешительность императора в отстаивании своей позиции, рейхсканцлер полагал, что «царя легче обмануть, чем парламент» (Бисмарк 1940b: 195). Он осознавал необходимость и полезность наличия рейхстага в Германии для ограничения монархии и сепаратизма династий. В значительной степени этому сдерживанию могли помогать, по мнению Бисмарка, умеренно действующие оппозиция и пресса (Бисмарк 1940а: 12).

Вместе с тем, Бисмарк опасался чрезмерного усиления влияния оппозиции в парламенте, и чтобы «притупить острие» этого влияния, считал важной для себя задачей не допустить «господства парламента в империи» (Бисмарк 1940b: 57). По требованию канцлера император даже несколько раз распускал парламент, если он вдруг не поддерживал какой-либо законопроект. Но причина роспусков рейхстага заключается не только в «неповиновении» канцлеру; Бисмарк полагал, что «своевременный роспуск после явных эксцессов большинства средством весьма целительным и самым верным ... для восстановления здорового кровообращения» (Бисмарк 1940а: 171). Кроме того, Бисмарк пытался сдерживать рейхстаг стимулированием работы других госучреждений, например, государственного совета Пруссии, организацией Совета народного хозяйства, расширением комиссий в бундесрате.
В своих выступлениях в парламенте Бисмарк предупреждал, что внутри законодательной власти борьбы фракций быть не должно, поскольку, по его мнению, от этого страдает вся Германская империя. Борясь друг с другом за власть, фракции забывают, как считал рейхсканцлер, о главных задачах страны, создавая такие политические программы, которые будут составлены не для государства, а ради борьбы с конкурентом (Бисмарк 1940b: 148). Бисмарк резко критиковал некоторых депутатов за то, что они не работают внимательно и усердно с законопроектами, погрузившись лишь во фракционную борьбу, слепо почитая своих партийных вождей и т. п. (Бисмарк 1940 b: 248).

Рейхсканцлер нуждался в поддержке таких депутатов парламента, которые могли помочь ему бороться с сепаративными тенденциями и ограничить возможное своеволие со стороны исполнительной власти. Для Бисмарка законодательная власть должна была занимать важное место; именно рейхстаг должен был разработать законодательство, относящееся к жгучим тогда социальным проблемам в Германии. Безусловно, идеи социального реформирования Бисмарка могли реализоваться только в рейхстаге.

Для принятия социального законодательства Бисмарку надо было подключить и еще один политический ресурс - предпринимательские классы, или, как тогда говорили и писали, «предпринимательские группы». Необходимо было создать прочную социальную опору общегерманского государства. Это была довольно сложная задача - рейхсканцлеру нужно было умело лавировать между политическими партиями и группами, предприпимательскими и иными социальными слоями.

С начала 1870-х гг. глава правительства Германской империи стал тесно общаться с крупными финансистами и промышленниками, используя их в своих социально-политических целях. Рейхсканцлер и сам был предпринимателем; в своем 
имении Варцин он владел двумя бумажными фабриками (Pflanze 2008: 36).

Главу немецкого правительства сблизили с промышленниками общие интересы в сфере экономического законодательства, стремление к развитию промышленности, потребность в защите предпринимательства от демократического движения, успехи в войнах с Францией и, наконец, создание единой империи.

Объединение Германии, как по национальным, так и по экономическим причинам, в предпринимательских кругах было встречено с восторгом. Первоначально осторожная позиция биржи при подписке на первый военный заем в 1870 году, явно продемонстрировавшая недоверие финансовых кругов государству, уступила место убежденности в целесообразности бисмарковского государственного порядка и - не без основания - в политическом величии главы правительства. Предприниматели стали рассматривать прусскую армию, для развития которой О. Бисмарк испрашивал у них финансы, как приоритетное политическое средство для решения национального вопроса. Они осознали, что для достижения экономического единства Германии необходимы сильная армия и военно-морской флот, которые позволят экономике и торговле государства развиваться без страха перед иностранным вмешательством (Zunkel 1962: 228-229).

Поддержка предпринимательства позволила рейхсканцлеру сблизиться со Свободно-консервативной партией, отстаивавшей интересы крупных промышленников (Zunkel 1962: 230). Бисмарк мог рассчитывать на свободных консерваторов в политике противодействия излишне активным, по мпениго рейхскапцлера, сторопникам либеральных реформ (Gall 1982: 323).

В первой половине XIX в. предприниматели вынуждены были бороться за свое признание в обществе со знатью, ремесленным и сельскохозяйственным сословием, служащими. Они не имели традиций, их происхождение от надомников или ско- пивших скромный капитал мастеров, сделало их непритязательными и беспощадными по отношению к себе и другим. В отношении своих работников они в основном не признавали никаких иных обязанностей, кроме выплаты заработной платы.

Жесткая конкурентная борьба, нехватка капитала и ликвидных средств, трудности сбыта препятствовали развитию их социальных установок. Из-за относительно благополучного положения промышленных рабочих в сравнении с сельскохозяйственными рабочими и поденщиками многим предпринимателям социальная политика казалась ненужной.

Тем не менее, отдельные немецкие промышленники вскоре после начала индустриализации начали заниматься производственными и внепроизводственными социальными проблемами, разработкой и реализацией социально-политических программ. Немецкий экономист Г. Геркнер написал в своем труде «Рабочий вопрос»: «Едва ли можно обнаружить социальную реформу, в осуществлении которой также работодатели ... не приняли бы участие».

Среди немецких предпринимателей XIX в. социально-политической активностью отличались Э. Аббе, Р. Бош, Г. Фризе, В. фон Функе, В. Охельхойзер, А. Крупп, барон К.Ф. фон Штумм-Гальберг, Л. Бааре и др.

Социально-политические концепции предпринимателей балансировали между двух полюсов. Одну сторону представляли А. Крупп и барон фон Штумм-Гальберг, другую - Э. Аббе.

А. Крупп и К.Ф. фон Штумм-Гальберг были представителями того патриархального, антидемократического, социал-феодалистского предпринимательства, которое активно поддерживал О. Бисмарк. С одной стороны, они признавали социальные обязанности по отношению к своему персоналу и щедро создавали социальные учреждения (Althammer, Lampert 2014: 43-45). Так, созданные А. Круппом учреждения в середине XIX в. считались образцовыми. 
Особенно известной стала его больничная касса (Wurm 1975: 62).

С другой стороны, занимая в феодально-аристократической манере жесткую позицию хозяина в доме, эти магнаты промышленности требовали дисциплины и послушания и верили в свое право опекать своих «подопечных» даже вне предприятия. Они отказывали своим работникам не только в праве голоса на заводе, но и стремились сделать их политически бесправными, препятствуя созданию рабочих объединений, профсоюзов и рабочих партий (Althammer, Lampert 2014: 43-45).

Напротив, Э. Аббе - опережая свое время - представлял демократическую, ориентированную на идею социального правового государства социально-политическую концепцию. Для него были естественными право на самоопределение для рабочих, защита человеческого достоинства, право рабочих на политическую деятельность, участие в управлении предприятием, участие в прибыли. В соответствии с этими принципами им была основана в 1889 г. фирма «Карл Цейсс Штифтунг», более известная как фонд имени Карла Цейсса. Целями этого благотворительного фонда являлись забота о развитии отраслей наукоемкой промышленности и оказание помощи в проведении научных работ в области математики и образования путем передачи средств университету в Йене (Althammer, Lampert 2014: 43-45).

Достаточно результативные социально-политические связи О. Бисмарк имел с «саарским угольным королем» К.Ф. фон Штумм Гальбергом и генеральным директором фирмы «Бохумерферайн» Л. Бааре. Эти связи еще более убедили Бисмарка в пеобходимости обязательного государственного страхования.

С некоторыми политическими партиями Бисмарк вел довольно жесткую дискуссию. К примеру, в 70-е гг. у него не складывались должные отношения с консервативной партией, поскольку та выступала в поддержку крупных аграрных собст- венников, которых Бисмарк, по большей части, относил к «непроизводящим классам», «бесполезным трутням» немецкого общества, не желающим управлять собственными землями. «Землевладелец, который живет в сельской местности, еще не самое плохое, самое плохое - это крупный землевладелец, который живет в городе, будь это Париж, Рим или Берлин, и от своих земель и владений требуют лишь денег, не представляя их в парламенте и даже не зная, как там идут дела. В этом состоит беда латифундий. Латифундии, чьи собственники живут на селе, при известных условиях являются большим благом и очень полезны» (Dove 2017: 281).

K так называемым «производящим народным классам» Бисмарк относил землевладельцев, промышленников и торговцев, сельскохозяйственных рабочих, ремесленников, т. е. те общественные слои, которые поддерживали существующий государственный порядок и, соответственно, были заинтересованы в его сохранении. От них он ожидал, что они не будут выдвигать политические теории, а отстаивать будут не «эгоистические» партийные, а практические экономические интересы (Born 1988: 76).

В 1875-1876 гг. Германия вступила в фазу стагнации, известную как «грюндерский кризис». Пострадали прежде всего металлургическая и текстильная промышленность от иностранной конкуренции. Ее представители возлагали ответственность за кризис сбыта на либеральную таможенную политику.

Вскоре промышленность получила поддержку от сельского хозяйства, прежде выступавшего за свободную торговлю. Мотивы для нового движегия в пользу покровительственных пошлин были основаны на начавшемся в 70-е гг. структурном аграрном кризисе. Во-первых, из-за роста населения Германия превратилась из страны, экспортирующей зерно, в импортирующую. Во-вторых, облегчение транспортировки по всему миру привело к тому, что 
восточноевропейские и трансатлантические страны стали составлять конкуренцию немецким сельхозпроизводителям на внутреннем рынке. Благодаря невысоким издержкам производства зарубежные поставщики продавали по более низким ценам, чем немецкие производители.

В таких условиях юнкерство требует защиты своих экономических интересов. В 1879 г. крупные землевладельцы выдвинули лозунг «Защита национального труда» и потребовали от правительства субсидировать юнкерские хозяйства (Бонвеч 2008а: 22-23).

В то время как прусский министр торговли без портфеля, президент канцелярии имперского канцлера и его правая рука Р. Дельбрюк и министр финансов Пруссии О. фон Кампгаузен к аграрно-индустриальному движению в пользу покровительственных пошлин отнеслись негативно, сам О. Бисмарк изменил свой курс за свободную торговлю и стал выступать за пересмотр тарифов, инициировав тем самым новую фазу протекционизма.

Цель реформы состояла в том, чтобы вернуть внутри страны спрос на местную промышленную и аграрную продукцию. Ставки таможенных пошлин по пересмотренным в 1879 г. тарифам оставались в целом ниже тех, которые существовали до этапа свободной торговли. Сутью реформы было восстановление ввозных таможенных пошлин на такое необходимое сырье и полуфабрикаты, как чугун, скот, зерно и пряжа.

Металлургическая промышленность добилась $20 \%$ покровительственной пошлины на сырье, в то время как сельское хозяйство - лишь 5-6\% хлебной пошлины. В том числе благодаря хлебюой пошлипе $\mathrm{O}$. Бисмарк надеялся обеспечить значительный рост доходов империи. Импорт зерна по его плану следовало не запретить полно- стью, а использовать в фискальных нуждах. Для империи пошлина образовала важнейший источник доходов, в то время как политика свободной торговли долгое время вела к финансовым потерям.

Тем самым, цель главы правительства по консолидации молодой империи не в последнюю очередь зависела от успеха его таможенной политики. Сверхплановая выручка в 82,2 млн марок превысила все ожидания. Удачная в налоговом отношении реформа таможенных тарифов в итоге привела к тому, что империя смогла справиться с растущими финансовыми потребностями, возникшими из-за возросших расходов в оборонном секторе и сфере социальной политики (Handwörterbuch der wirtschaftswissenschaft 1982: 655).

К 1879 г. О. Бисмарк добился с помощью покровительственных тарифов союза крупных предпринимателей и землевладельцев, т. е. объединения финансовой и социальной элиты. Он также убедился, к собственному удовлетворению, что покровительственные тарифы способствуют падению цен на промышленную продукцию, став бременем для иностранного производителя, но не немецкого потребителя, а также эффективно защищают внутренний рынок от иностранной конкуренции, способствуя увеличению прибыли немецких работодателей и повышению зарплат немецким рабочим. Таким образом, «покровительственные тарифы» О. Бисмарка следует рассматривать в рамках социальной политики.

Итак, Бисмарк, преобразуя разнонаправленные интересы в устойчивый политический альянс, лавируя между различными социальными слоями и политическими группами, руководствовался целыо создания надежной социальной опоры общегерманского государства. 


\section{ЛИТЕРАТУРА}

Бисмарк О. 1940а. Мысли и воспоминания: В 3 т. / Пер. с нем. под ред. проф. Л.С. Ерусалимского. М.: ОГИЗ. Т. 1.

Бисмарк О. 1940b. Мысли и воспоминания: В 3 т. / Пер. с нем. под ред. проф. Л.С. Ерусалимского. М.: ОГИЗ. Т. 2

Бонвеч Б. 2008а. История Германии: В 3 т. Т. 2: От создания Германской империи до начала XXI века / Под общ. ред. Б. Бонвеча, Ю.В. Галактионова. М.: КДУ.

Бонвеч Б. 2008b. История Германии: В 3 т. Т. 3: Документы и материалы / Под общ. ред. Б. Бонвеча, Ю.В. Галактионова. М.: КДУ.

Ольховская О.В. 2014. Партия «Центр» в Германии 70-х годов XIX века: организация, идеология, политическая практика: Дис. ... канд. ист. наук. Брянск.

Ренненкампф В.Н. 1890. Конституционные начала и политические воззрения Бисмарка. Киев: Тип. высоч. утв. Т-ва Кушнерев и $\mathrm{K}^{\circ}$ в Москве, Киевское отд.

Устинова Ю.Н. 2011. Национал-либеральная партия в политической жизни Германии: 1871-1878 годы: Дис. ... канд. ист. наук. Брянск.

Чупрова О.В. 2009. Взгляды О. Бисмарка на место и роль законодательной власти в Германии во второй половине XIX века // Пробелы в российском законодательстве. Юридический журнал. Вып. 4, 309-312. Althammer J.W., Lampert H. 2014. Lehrbuch der Sozialpolitik. Berlin Heidelberg Springer: Verlag Berlin Heidelberg.

Born K.E. 1988. Kräfte und Ideen // hrgb. von Hohmann K., Wünsche H. F. Grundtexte zur sozialen Marktwirtschaft. Bd. 2. Das Soziale in der Sozialen Marktwirtschaft. Stuttgart/New York: Gustav Fischer Verlag.

Dove A. 2017. Fürst Bismarck als Redner: Die Reichstagssession von 1884/85. Salzwasser: Verlag Verone.

Gall L. 1982. Bismarcks Preußen, das Reich und Europa // Historische Zeitschrift. Bd. 234. H. 2. Berlin: Oldenbourg Wissenschaftsverlag $\mathrm{GmbH}$.

Handwörterbuch der wirtschaftswissenschaft (HdWW). 1982. Bd. 9. Wirtschaft und Politik bis Zölle, Nachtrag / Zottmann A. (Redaktion). Tübingen: Gustav Fischer - J.C.B. Mohr, Göttingen und Zürich: Vandenhoeck und Ruprecht.

Pflanze O. 2008. Bismarck: Der Reichskanzler. München: Verlag C.H. Beck.

Ritter G.A., Niehuss M. 1980. Wahlgeschichtliches Arbeitsbuch. Materialien zur Statistik des Kaiserreich 1871-1918. München: C.H. Beck, 38-43.

Salomon F. 1924. Die deutschen Parteiprogramme vom Erwachen des politischen Lebens in Deutschland bis zur Gegenwart. Heft 2. Im deutschen Kaiserreich 1871-1918. Leipzig.

Specht F. 1898. Die Reichstags Wahlen von 1867 bis 1897 . Eine Statistik der Reichstagswahlen nebst den Programmen den Parteien und dem Verzeichniß der gewählten Kandidaten. Berlin.

Treue W. 1956. Deutschen Parteiprogramme 1861-1956. Göttingen.

Wurm F.F. 1975. Wirtschaft und Gesellschaft in Deutschland 1848-1948. Opladen: Leske Verlag,

Zunkel F. 1962. Der Rheinisch-Westfalische Unternehmer 1834-1879. Ein Beitrag zur Geschichte des deutschen Bürgertums im 19. Jahrhundert. (Dortmunder Schriften zur Sozialforschung). Bd. 19. Köln und Opladen: Westdeutscher Verlag.

\section{REFERENCES}

Bismark O. 1940. Mysli i vospominaniya.Vol. 1. Moscow. (In Russian).

Bismark O. 1940. Mysli i vospominaniya.Vol. 2. Moscow. (In Russian).

Bonvech B. 2008. Istoriya Germanii. Vol. 2. InOt sozdaniya Germanskoi imperii do nachala XXI veka. Moscow. (In Russian).

Bonvech B. 2008. Istoriya Germanii. Vol. 3. In Dokumenty i materialy. Moscow. (In Russian).

Ol'khovskaya O.V. 2014. Partiya "Tsentr" v Germanii 70-kh godov XIX veka: organizatsiya, ideologiya, politicheskaya praktika: candidate's thesis. Bryansk. (In Russian).

Rennenkampf V.N. 1890. Konstitutsionnye nachala i politicheskie vozzreniya Bismarka. Kiev. (In Russian).

Ustinova Yu.N. 2011. Natsional-liberal'naya partiya v politicheskoi zhizni Germanii: 1871-1878 gody: candidate's thesis. Bryansk. (In Russian).

Chuprova O.V. 2009. Vzglyady O. Bismarka na mesto i rol' zakonodatel'noi vlasti v Germanii vo vtoroi polovine XIX veka. Probely v rossiiskom zakonodatel'stve. Yuridicheskii zhurnal. Issue. 4, 309-312. (In Russian). Heidelberg. Althammer J.W., Lampert H. 2014. Lehrbuch der Sozialpolitik. Berlin Heidelberg Springer: Verlag Berlin Born K.E. 1988. Kräfte und Ideen. New York. 
Dove A. 2017. Fürst Bismarck als Redner: Die Reichstagssession von 1884/85. Salzwasser.

Gall L. 1982. Bismarcks Preußen, das Reich und Europa. Historische Zeitschrift. Bd. 234. H. 2. Berlin.

Handwörterbuch der wirtschaftswissenschaft (HdWW). 1982. Bd. 9. Wirtschaft und Politik bis Zölle, Nachtrag. In Tübingen: Gustav Fischer - J.C.B. Mohr, Göttingen und Zürich: Vandenhoeck und Ruprecht.

Pflanze O. 2008. Bismarck: Der Reichskanzler. München

Ritter G.A., Niehuss M. 1980. Wahlgeschichtliches Arbeitsbuch. In Materialien zur Statistik des Kaiserreich 1871-1918. München, 38-43.

Salomon F. 1924. Die deutschen Parteiprogramme vom Erwachen des politischen Lebens in Deutschland bis zur Gegenwart. Heft 2. Im deutschen Kaiserreich 1871-1918. Leipzig.

Specht F. 1898. Die Reichstags Wahlen von 1867 bis 1897. Eine Statistik der Reichstagswahlen nebst den Programmen den Parteien und dem Verzeichniß der gewählten Kandidaten. Berlin.

Treue W. 1956. Deutschen Parteiprogramme 1861-1956. Göttingen.

Wurm F.F. 1975. Wirtschaft und Gesellschaft in Deutschland 1848-1948. Opladen.

Zunkel F. 1962. Der Rheinisch-Westfalische Unternehmer 1834-1879. Ein Beitrag zur Geschichte des deutschen Bürgertums im 19. Jahrhundert. (Dortmunder Schriften zur Sozialforschung). Bd. 19. Köln und Opladen: Westdeutscher Verlag.

L. N. Bespalova

Nizhnevartovsk, Russia

\title{
GERMAN POLITICAL PARTIES AS A RESOURCE FOR SOCIAL REFORM IN GERMANY IN THE 70 ${ }^{\mathrm{S}}$ OF THE XIX CENTURY
}

\begin{abstract}
The paper analyzes the role of political parties and other political resources in the context of social reform in the German Empire in the 1870s. Not only political parties and movements, but also professional associations, entrepreneurial groups that demonstrate a certain degree of social responsibility are referred to political resources. The indicated period in Reich Chancellor O. Bismarck's domestic policy was marked by an active search for like-minded people represented by representatives of various political parties, economists, and large industrialists for social reforms development and implementation. It is proved that in search of the all-German social support, O. Bismarck demonstrated the ability to maneuver between political parties and groups, business and other social strata. The study focuses on Reich Chancellor's strategy was aimed at reducing the severity of political and social problems and creating a social balance between different social strata. The author emphasizes that the head of the German government not only sought to isolate the working class out of the social democracy through social concessions, but also to maintain peace and harmony in new industrial society, open the way to its consolidation, which was supposed to come to stability through social reforms. The author pays particular attention to the structure, organization and influence of the political parties. The study provides the statistical data on the share of voters who voted for the parties and the number of deputy mandates received from the results of general elections, as well as describes various political programs.
\end{abstract}

Key words: party; liberals; conservatives; progressives; social democrats; Otto von Bismarck, parliament; Reichstag; cadets.

About the author: Lyudmila Nikolaevna Bespalova, Senior Lecturer of the Department for Documentation Studies and General History.

Place of employment: Nizhnevartovsk State University.

Беспалова Л.Н. Политические партии как ресурс для социального реформирования Германии в 70 -е годы XIX века // Вестник Нижневартовского государственного университета. 2019. № 3. С. 23-32.

Bespalova L.N. German political parties as a resource for social reform in Germany in the $70^{\mathrm{s}}$ of the XIX century // Bulletin of Nizhnevartovsk State University. 2019. No. 3. P. 23-32. 